\title{
PENERAPAN MODEL PEMBELAJARAN KOLABORATIF DENGAN TEKNIK LEARNING CELL PADA MATERI KELARUTAN DAN HASIL KALI KELARUTAN PADA SISWA KELAS XI SMA NEGERI 6 PALU
}

\author{
Implementation of Collaborative Learning Model with Learning Cell Technique on the Topic of \\ Solubility and Solubility Products on the Students in Class XI SMAN 6 Palu
}

\author{
*Putri Ningsi A. Panontji, Sri Mulyani Sabang dan Kasmudin Mustapa
}

Pendidikan Kimia/FKIP - Universitas Tadulako, Palu - Indonesia 94118

Received 20 March 2018, Revised 20 April 2018, Accepted 18 May 2018

\begin{abstract}
This study was conducted to determine the difference on students learning outcomes in the classroom implemented with collaborative learning model using cell learning technique on the topic of solubility and solubility product in the class XI at SMAN 6 Palu. This study was a quasi-experiment research with pretestposttest control group design. Population in this study were students of class XI IPA at SMAN 6 Palu enrolled in the academic year of 2015-2016 amounting to 43 student. Sampling technique was a sampling saturated. Samples in this study were 21 students in the class XI IPA2 as the experimental class, and 22 students in the class XI IPAI as the control class. The results showed that the output rank for the mean value of the experimental class was bigger than the control class, $30.29>14.09$. The output statistic test showed sig. 2-tailed $0.00<0.05$, and $Z_{\text {count }}(-4.25)<Z_{\text {table }}(-1.64)$. These mean that $H_{0}$ was rejected and $H_{a}$ was received. Therefore, it can be concluded that there is significant difference in learning outcomes between the class which implement collaborative learning model with learning cell technique, and the classes which implement traditional learning model on the topic of solubility and solubility product in the Class XI at SMAN 6 Palu.
\end{abstract}

Keywords: Collaborative learning, learning cell, solubility and solubility product, nonparametric, mann whitney utest.

\section{Pendahuluan}

Pendidikan adalah usaha sadar yang sengaja dirancangkan untuk mencapai tujuan yang telah ditetapkan. Hal ini sejalan dengan tujuan pendidikan yaitu untuk meningkatkan kualitas sumber daya manusia. Salah satu usaha untuk meningkatkan kualitas sumber daya manusia ialah melalui proses pembelajaran di sekolah (Yuditia, 2013).

Setiap sekolah diberikan kebebasan untuk mengembangkan bahan ajar sendiri sehingga guru dituntut untuk kreatif dan inovatif. Materi ajar dapat dikembangkan sesuai dengan kebutuhan kompetensi siswa, salah satu cara yang dapat dilakukan adalah dengan membuat suasana belajar yang menyenangkan bagi siswa baik dari model pembelajaran yang digunakan atupun variasi metode pembelajaran yang akan diterapkan di dalam kelas (Purnamasari, dkk., 2013).

Salah satu model pembelajaran yang dapat diterapkan dalam proses pembelajaran di sekolah adalah model pembelajaran kolaboratif. Pembelajaran kolaboratif adalah jenis pembelajaran aktif pada sekelompok siswa. Pembelajaran aktif merupakan pendekatan pembelajaran yang lebih

*Correspodence

Putri Ningsi A. Panontji

Program Studi Pendidikan Kimia, Fakultas Keguruan dan Ilmu Pendidikan, Universitas Tadulako

e-mail:pningsi94@yahoo.co.id

Published by Universitas Tadulako 2018 banyak melibatkan aktivitas siswa dalam mengakses berbagai informasi dan pengetahuan untuk dibahas dan dikaji dalam pembelajaran di kelas, sehingga mereka mendapat berbagai pengalaman yang menigkatkan pemahaman dan kompetensinya (Tati, dkk., 2015).

Metode pembelajaraan kolaboratif (collaborative learning) merupakan metode pembelajaran yang menerapkan paradigma baru dalam teori-teori belajar, khususnya pembelajaran konstruktivisme (Dermawan, 2014). Pembelajaran kolaboratif ini berpusat pada siswa, penemuan, belajar dan penggunaan informasi dalam cara kolaboratif, bukan instruktur hanya ceramah dan siswa secara individual, mengambil catatan pasif (Bhujbal, 2014).

Berdasarkan usulan Kirschner, dkk., (2008) bahwa hasil belajar pada umumnya meningkatkan kegiatan belajar ketika kolaboratif menggunakan beberapa teknik scripting (misalnya, diajarkan strategi tim, peran yang ditetapkan, siswa dipantau). Jika kegiatan kolaboratif dapat digunakan secara efektif untuk meningkatkan pembelajaran, mungkin bisa digunakan untuk menggantikan teknik ceramah.

Salah satu jenis teknik pengajaran pada model pembelajaran kolaboratif yakni learning cell atau sel pembelajaran. Learning cell merupakan suatu bentuk belajar secara berpasangan, dimana siswa bertanya dan menjawab pertanyaan secara bergantian berdasarkan materi bacaan yang sama (Istarani, 2012). Teknik pembelajaran ini memberikan kesempatan siswa saling bertanya satu 
sama lain menggunakan pertanyaan yang mereka buat sendiri mengenai bacaan yang ditugaskan atau kegiatan belajar lainnya. Tujuan dari learning cell ini adalah melibatkan siswa secara aktif dalam berpikir mengenai konten pembelajaran untuk mendorong siswa memunculkan pertanyaanpertanyaan yang memancing perenungan dan mengajarkan siswa bagaimana cara memeriksa pemahaman mereka (Barkley, dkk., 2014).

Tulisan ini dimaksudkan untuk melihat perbedaan hasil belajar siswa pada kelas yang diberi penerapan model pembelajaran kolaboratif dengan teknik learning cell dengan kelas yang diberi model pembelajaran ceramah, pada materi kelarutan dan hasil kali kelarutan pada siswa kelas XI SMA Negeri 6 Palu.

\section{Metode}

Penelitian ini dilaksanakan di SMA Negeri 6 Palu. Sampel merupakan bagian dari jumlah karakteristik yang dimiliki oleh populasi. Populasi dalam penelitian ini adalah kelas XI IPA di SMA Negeri 6 Palu yang terdaftar pada tahun ajaran 2015/2016 yang terdiri dari 2 kelas. Teknik pengambilan sampel yang digunakan adalah pengambilan sampel secara sampling jenuh. Dari hasil penentuan sampel di peroleh yaitu kelas XI IPA1 dengan jumlah siswa sebanyak 22 orang dan kelas XI IPA2 dengan jumlah siswa sebanyak 21 orang. Penentuan kelas eksperimen dan kelas kotrol dari kedua sampel kelas berdasarkan hasil pretest yang diperoleh.

Desain atau rancangan yang digunakan pada penelitian ini yaitu desain pretest posttest control group. Desain ini merupakan salah satu desain yang tergolong eksperimen semu (quasi experimental research) dimana pada desain ini pemilihan subjek kelompok tidak dilakukan dengan acak (random), misalnya eksperimen di suatu kelas tertentu dengan siswa yang telah ada atau sebagaimana adanya (Sudjana \& Ibrahim, 2012).

Instrumen yang digunakan pada penelitian ini adalah tes hasil belajar bentuk pilihan ganda yang awalnya sebanyak 40 soal menjadi 20 soal pilihan yang tervalidasi. Hasil pengujian validitas butir soal, daya pembeda, tingkat kesukaran dan reliebilitas tes menggunakan software Anates V4.0.9 (Fuad, 2015). Tipe soal adalah pilihan ganda.

Tes ini digunakan sebagai tes awal (pretest) dan tes akhir (posttest) untuk mengetahui perbedaan basil belajar kelas kontrol dan eksperimen sebelum dan setelah penerapaan model pembelajaraan dalam proses pebelajaran. Melalui alat ini diharapkan dapat mengungkapkan data penguasaan siswa terhadap konsep kimia untuk pokok bahasan kelarutan dan hasil kali kelarutan yang mendapat perlakuan dengan model pembelajaran kolaboratif dengan teknik learning cell dan model pembelajaran ceramah.

\section{Teknik Pengumpulan Data}

\section{Tahap persiapan}

Langkah-langkah yang dilakukan pada tahap ini, yaitu observasi lokasi penelitian yakni di SMA Negeri 6 Palu, menentukan populasi dan sampel penelitian, Menyusun rencana pelaksanaan pembelajaran (RPP), instrumen tes hasil belajar serta lembar kerja siswa yang akan digunakan dalam penelitian untuk kelas eksperimen dan kelas kontrol. Rencana pelaksanaan pembelajaran yang digunakan pada penelitian ini mengacu pada KTSP dari pusat kurikulum yang meliputi pokok bahasan kelarutan dan hasil kali kelarutan.

\section{Tahap pelaksanaan}

Langkah-langkah yang dilakukan pada tahap ini, yaitu melakukan pretest untuk memperoleh data awal tentang kemampuan awal siswa. Melaksanakan kegiatan belajar mengajar menggunakan model pembelajaran kolaboratif dengan teknik learning cell pada kelas eksperimen dan melakukan kegiatan belajar mengajar menggunakan model pembelajaran ceramah pada kelas kontrol. Selanjutnya melakukan posttest sebagai evaluasi pada akhir pengajaran, untuk memperoleh data akhir (tes akhir) baik pada kelas eksperimen maupun kelas kontrol.

\section{Tahap akhir}

Kegiatan yang dilakukan pada tahap ini adalah pengolahan dan analisis data serta pelaporan data hasil penelitian. Teknik analisis data menggunakan metode statistik non parametrik untuk menguji hipotesis yang akan menentukan kita dalam menarik kesimpulan terhadap penerapan model pembelajaran kolaboratif dengan teknik learning cell. Statistik non parametrik digunakan untuk menganalisis data dengan tidak dilandasi persyaratan data harus berdistribusi normal. Penentuan uji statistik juga ditentukan oleh jumlah data yang di analisis, bila jumlah data kecil $(<30)$ cenderung digunakan uji non parametrik (Riyanto, 2013). Pengujian hipotesis yang digunakan pada penelitian ini adalah uji Mann-Whitney U-Test. Utest ini digunakan untuk menguji hipotesis komparatif dua sampel independen (Sugiyono, 2010).

\section{Hasil dan Pembahasan}

Data penelitian berasal dari nilai pretest dan postest yang menggunakan tes tertulis berupa soal pilihan ganda yang sebelumnya telah divalidasi dan menghasilkan 20 soal tes yang valid.

Sebelum pembelajaran dilaksanakan, terlebih dahulu dilaksanakan pretest pada kedua kelas untuk mengetahui kemampuan awal siswa pada kedua kelas sampel mengenai materi kelarutan dan hasil kali kelarutan. Kemampuan awal siswa yang dinilai melalui pretest aspek kognitif siswa. Kemampuan awal siswa dinilai dari jawaban soal pilihan ganda berjumlah 20 butir soal yang telah divalidasi terlebih dahulu. Hasil analisis data pretest siswa diperoleh seperti terlihat pada Tabel 1. 
Tabel 1. Hasil analisis data pretest

\begin{tabular}{ccc}
\hline \multirow{2}{*}{ Uraian } & \multicolumn{2}{c}{ Tes Awal ( Pretest) } \\
\cline { 2 - 3 } & $\begin{array}{c}\text { Kelas } \\
\text { kontrol }\end{array}$ & $\begin{array}{c}\text { Kelas } \\
\text { eksperimen }\end{array}$ \\
\hline Sampel & 22 orang & 21 orang \\
Nilai terendah & 10 & 10 \\
Nilai tertinggi & 50 & 55 \\
Banyaknya siswa yang & 22 orang & 21 orang \\
belum tuntas & 36 & 24,05 \\
Nilai rata-rata & &
\end{tabular}

dan hasil kali kelarutan kelas XI SMA Negeri 6 Palu.

Hasil analisis pengujian, untuk variabel hasil belajar yaitu $Z_{\text {hitung }}<Z_{\text {tabel }}$, Asymp.Sig. (2-tailed) $<$ alpha. Dengan hasil tersebut maka dapat disimpulkan bahwa hipotesis yang diajukan adalah menolak $\mathrm{H}_{0}$ dan menerima $\mathrm{H}_{\mathrm{a}}$, yaitu model pembelajaran learning cell dapat diterapkan pada materi kelarutan dan hasil kali kelarutan kelas XI SMA Negeri 6 Palu. Deskripsi data untuk pengujian hipotesis disajikan seperti pada Tabel 3.

Tabel 3. Deskripsi hasil analisis data untuk pengujian hipotesis

\begin{tabular}{|c|c|c|c|c|c|c|c|}
\hline Variabel & Kelas & Rerata & $Z_{\text {hitung }}$ & $\begin{array}{l}Z_{\text {tabel }} \\
(0,05 / 2)\end{array}$ & P. Sig & $\alpha$ & Kesimpulan \\
\hline $\begin{array}{l}\text { Hasil } \\
\text { Belajar }\end{array}$ & $\begin{array}{c}\text { Eksperimen } \\
\text { Kontrol }\end{array}$ & $\begin{array}{l}30,26 \\
14,09\end{array}$ & $-4,25$ & $-1,64$ & 0,000 & 0,05 & $\mathrm{H}_{\mathrm{a}}$ diterima \\
\hline
\end{tabular}

Berdasarkan hasil tersebut, bahwa rata-rata nilai pretest kelas XI IPA1 lebih tinggi dari pada rata-rata nilai pretest kelas XI IPA2, sehingga dapat disimpulkan bahwa kemampuan awal siswa kelas XI IPA1 lebih baik dari kemampuan siswa kelas XI IPA2. Sehingga dapat ditetapkan bahwa kelas XI IPA2 sebagai kelas eksperimen dan kelas XI IPA1 sebagai kelas kontrol dilihat dari nilai hasil pretest.

Berdasarkan penelitian yang dilakukan, didapatkan data posttest siswa kelas eksperimen dan kelas kontrol, seperti dijabarkan dalam Tabel 2.

Tabel 2. Hasil analisis data posttest

\begin{tabular}{ccc}
\hline \multirow{2}{*}{ Uraian } & \multicolumn{2}{c}{ Tes Akhir (Posttest) } \\
\cline { 2 - 3 } & $\begin{array}{c}\text { Kelas } \\
\text { kontrol }\end{array}$ & $\begin{array}{c}\text { Kelas } \\
\text { eksperimen }\end{array}$ \\
\hline Sampel & 22 orang & 21 orang \\
Nilai terendah & 35 & 50 \\
Nilai tertinggi & 90 & 95 \\
Banyaknya siswa yang & 17 orang & 8 orang \\
belum tuntas & 67,04 & 74,285 \\
Nilai rata-rata &
\end{tabular}

Hasil menunjukkan bahwa rata-rata nilai posttest siswa kelas eksperimen yang sebesar 74,285 lebih tinggi daripada rata-rata nilai posttest siswa kelas kontrol yang sebesar 67,04. Dengan demikian dapat terbukti bahwa dengan menerapkan model pembelajaran yang sesuai dapat meningkatkan hasil belajar siswa, ini dapat dilihat dari rata-rata nilai posttest siswa kelas eksperimen yang diajarkan melalui model pembelajaran learning cell dan rata-rata nilai posttest siswa kelas kontrol yang diajar melalui model pembelajaran ceramah.

Hasil dari analisis Mann-Whitney U-test akan memenuhi kriteria pengujian hipotesis $\mathrm{H}_{\mathrm{a}}$ diterima dan $\mathrm{H}_{0}$ ditolak jika, $\mathrm{U}_{\text {hitung }}$ lebih kecil dari $\mathrm{U}_{\text {tabel, }}$ untuk sampel berjumlah maksimal 20 orang. Penelitian ini, sampel berjumlah 21 orang pada kelas eksperimen dan 22 orang pada kelas kontrol, maka pengujian hipotesisnya menggunakan pendekatan tabel $Z$. Adapun hipotesis yang diajukan dalam penelitian ini adalah ada perbedaan hasil belajar siswa setelah menerapkan model pembelajaran learning cell pada materi kelarutan

\section{Pengujian hipotesis}

Penelitian ini menggunakan taraf kepercayaan 0,05 karena diharapkan dalam pengambilan kesimpulan, kesalahan yang terjadi hanya 5\% dan 95\% darinya benar. Dari hasil pengujian hipotesis yang dilakukan, maka dapat disimpulkan bahwa nilai hasil belajar kelas eksperimen (menggunakan model pembelajaran learning cell) lebih baik dari pada kelas kontrol (menggunakan model pembelajaran ceramah).

Perbedaan hasil belajar siswa pada kelas eksperimen dan kelas kontrol disebakan karena adanya pengaruh model pembelajaran yang diterapkan di kelas tersebut. Hasil belajar siswa kelas eksperimen lebih baik dibandingkan dengan kelas kontrol karena di kelas tersebut diterapkan model pembelajaran kolaboratif dengan teknik learning cell. Metode pembelajaran learning cell memiliki kelebihan-kelebihan yang tidak dimiliki oleh tipe pembelajaran berpasangan lainnya.

Beberapa hal yang menjadi kelebihan pembelajaran dengan menggunakan metode pembelajaran learning cell di antaranya adalah siswa lebih siap dalam menghadapi materi yang akan dipelajari karena siswa telah memiliki informasi materi yang akan dipelajari melalui berbagai sumber di antaranya buku, internet, guru, dan orang yang ahli di bidang materi tersebut. Siswa akan memiliki kepercayaan diri dalam pembelajaran, karena pembelajaran ini menggunakan teman sebaya dalam proses pembelajarannya. Siswa yang ditutori tidak akan segan-segan dalam memberikan pertanyaan yang tidak dipahami. Sebaliknya bagi siswa tutor selain pengetahuannya bertambah, kemampuan dalam mengkomunikasikan ilmu pengetahuan pada teman sebaya meningkat (Nadhifah, 2009).

Kelebihan lain dari model pembelajaran kolaboratif dengan teknik learning cell mengacu pada sebuah format pembelajaran dengan memasangkan para siswa dimana siswa bertanya dan menjawab bergiliran berdasarkan tentang suatu tugas para siswa dituntut untuk berpikir tentang isi materi, hal ini berbeda dengan hanya menulis catatan pada saat pembelajaran. Hal ini 
meberikan suatu kesempatan untuk siswa untuk berpikir secara analitis, terperinci ketika mereka memasukkan materi ke dalam kata-kata mereka sendiri, dan menggunakan bahasa yang benar (Rakhmawati, 2015). Learning cell juga dapat mendorong siswa untuk lebih aktif dalam mengemukakan pendapat dan pertanyaan (Suprijono, 2009).

Namun pada penerapan model pembelajaran ini di kelas eksperimen terdapat kendala, dimana pada kelas tersebut siswa kekurangan pegangan literatur untuk membaca dan mempelajari mengenai materi yang diajarkan, dimana para siswa hanya memiliki LKS yang digunakan dalam proses pembelajaran. Namun hal ini dapat diantisipasi dengan menganjurkan siswa untuk membaca buku-buku yang relevan atau melalui internet (Zaini, 2008).

Kendala lain yang dialami dalam penerapan model pembelajaran ini yaitu siswa kesulitan dalam membuat soal dari bahan bacaan yang mereka pelajari, dan karena kendala ini para siswa membutuhkan waktu yang lama dalam membuat soal serta jawaban dari soal tersebut. Sehingga, untuk mengatasi masalah tersebut dan proses pembelajaran tetap terlaksana sesuai waktu yang ditentukan, maka siswa harus membuat tugas soal dan jawaban mengenai materi yang akan diajarkan untuk pertemuan selanjutnya dari rumah mereka sebelum pertemuan di kelas, tugas tersebut dihitung sebagai pekerjaan rumah.

Untuk keberhasilan metode ini diperlukan pengawasan dan bimbingan kepada siswa dalam proses pembelajaran, karena berdasarkan hasil riset menunjukkan pembelajaran kolaboratif yang efektif memerlukan lebih dari sekedar membentuk kelompok dan menugaskan tugas (Hamalainen \& Arvaja, 2009). Sehingga pengawasan serta bimbingan kepada siswa dalam proses pembelajaran sangat diperlukan agar para siswa dapat melakukan tugas yang diberikan dengan baik dan proses pembelajaran dapat berlangsung dengan lancar.

Berbeda dengan kelas eksperimen yang menerapkan model pembelajaran kolaboratif dengan teknik learning cell, model pembelajaran yang diterapkan di kelas kontrol adalah model pembelajaran ceramah yang hanya berpusat pada guru sehingga aktivitas siswa menjadi pasif. Kelas kontrol dengan menggunakan penerapan model pembelajaran ceramah, dimana saat kegiatan pembelajaran berlangsung siswa hanya duduk dan memperhatikan guru menjelaskan materi yang dipelajari. Suasana pembelajaran tersebut cenderung membuat siswa pasif dalam proses pembelajaran, sehingga daya pikir siswa tidak berkembang secara optimal, serta cenderung membuat siswa tidak termotivasi mengikuti pembelajaran. Sehingga dapat membuat siswa yang memiliki keterampilan mendengarkan rendah akan cepat merasa bosan dan terpecah perhatiannya.

\section{Kesimpulan}

Output rank untuk nilai mean kelas eksperimen lebih besar dari kelas kontrol yaitu 30,29>14,09. Output test statistic, sig. 2-tailed $0,00<0,05$ dan $Z$ hitung $(-4,25)<Z$ tabel $(-1,64)$. Dari hasil pengujian hipotesis yang dilakukan, maka $\mathrm{H}_{0}$ ditolak dan $\mathrm{H}_{a}$ diterima sehingga dapat disimpulkan bahwa terdapat perbedaan yang signifikan pada hasil belajar antara kelas yang menerapan model pembelajaran kolaboratif dengan teknik learning cell, dan kelas yang menerapkan model pembelajaran ceramah pada materi kelarutan dan hasil kali kelarutan di kelas XI SMA Negeri 6 Palu.

\section{Ucapan Terima Kasih}

Penulis mengucapkan terima kasih kepada kepala sekolah SMA Negeri 6 Palu, guru kimia di SMA Negeri 6 Palu, siswa-siswa kelas XI IPA SMA Negeri 6 Palu serta semua pihak yang telah membantu penulis dalam penyelesaian penelitian ini.

\section{Referensi}

Barkley, E. E., Cross, K. P., \& Major, C. H. (2014). Collaborative learning techniques. Bandung: Nusa Media.

Bhujbal, P. C. (2014). A model for effectual collaborative learning. Bonfring International Journal of Industrial Engineering and Management Science, 4(1), 1-7.

Dermawan, A. (2014). Keefektifan collaborative learning berbasis quiz edutainment terhadap ketuntasan hasil belajar. Chemistry in Education, 3(1), 1-6.

Fuad, M. F. (2015). Perbedaan hasil belajar biologi siswa dengan menggunakan model pembelajaran problem based learning dan project based learning pada konsep fungi (Diterbitkan), Jakarta: Universitas Islam Negeri Syarif Hidayatullah.

Hamalainen, R., \& Arvaja, M. (2009). Scripted collaboration and group-based variations in a higher education CSCL context. Scandinavian Journal of Educational Research, 53, 1-16.

Istarani. (2012). Model pembelajaran. Jakarta: Media Persada.

Kirschner, F., Pass, F., \& Kirschner, P. A. (2008). A cognitive load approach to collaborative learning: United brains for complex tasks. Educational Psychology Review, 21, 31-42.

Nadhifah. (2009). Pengaruh strategi learning cell terhadap motivasi belajar siswa pada mata pelajaran fiqih. (Skripsi Tidak Dipublikasikan), Surabaya: PAI IAIN.

Purnamasari, M., Sukardjo, J. S., \& Nugroho, A. (2013). Studi komparasi pembelajaran kooperatif tipe number head together (nht) dan make a match pada materi koloid terhadap prestasi belajar siswa kelas XI SMA Negeri 
Kebakkramat tahun pelajaran 2011/2012. Jurnal Pendidikan Kimia (JPK), 2(1), 67-72.

Rakhmawati, D. (2015). Learning cell technique toward reading comprehension of narrative text. SMART Journal, 1(2), 42-56.

Riyanto, A. (2013). Statistik inferensial. Yogyakarta: Nuha Medika.

Sudjana, N., \& Ibrahim. (2012). Penelitian dan penilaian pendidikan. Bandung: Sinar Baru Algensindo.

Sugiyono. (2010). Statistik nonparametrik. Bandung: Alfabeta.
Suprijono, A. (2009). Cooperative learning teori \& aplikasi PAIKEM. Yogyakarta: Pustaka Belajar.

Tati, Suhartono, \& Najah, T. S. (2015). Penerapan strategi pembelajaran aktif tipe the learning cell pada pokok bahasan bunyi. EduSains, 3(1), 26-36.

Yuditia, P. R. (2013). Studi komparasi metode pembelajaran the learning cell dengan metode pembelajaran artikulasi terhadap hasil belajar teknologi informasi dan komunikasi (TIK). Kumpulan Artikel Siswa Pendidikan Teknik Informatika, 2(6), 790-795.

Zaini, H. (2008). Strategi pembelajaran aktif. Yogyakarta: Pustaka Insan Madani. 